\title{
Customer Satisfaction in Online Shopping: a study into the reasons for motivations and inhibitions
}

\author{
Rashed Al Karim \\ (Assistant Professor, Business Administration, East Delta University, Bangladesh)
}

\begin{abstract}
This study endeavours to understand customer satisfaction in online shopping while investigating the major reasons that motivated customers' decision-making processes as well as inhibitions of online shopping. The Kotler and Killers (2009) Five Stage Buying Process Model was chosen as the basis of framework of this study to explain customer satisfaction through their motivations to buy products online. The existing literature was reviewed to discover reasons that would influence customers positively or negatively towards shopping online. Surveys were conducted by distributing questionnaires in the Wrexham area (North Wales) to gather data for this research. SPSS software package was used to present research data graphically and to test research hypothesis. From the findings, it was discovered that respondents use internet to purchase products through online because they believe it is convenience to them and the term convenient includes elements such as time saving, information availability, opening time, ease of use, websites navigation, less shopping stress, less expensive and shopping fun. In contrast, along with respondents' mind-sets, online payment security, personal privacy and trust, unclear warranties and returns policies and lack of personal customer service are the foremost barriers of online shopping. Furthermore, the result of hypotheses established that even though online shopping is convenient to all consumers, online payment system and privacy or security anxieties have significant impact on online shopping. Finally, some recommendations have been offered for online retailers to take initiatives for making online shopping more admired and trustworthy.
\end{abstract}

Keywords: Customer satisfaction, Customer motivation and inhibition, On-line shopping, On-line vendor, SPSS software.

\section{Introduction}

With the rapid global growth in electronic commerce (e-commerce), businesses are attempting to gain a competitive advantage by using e-commerce to interact with customers (Demangeot and Broderick, 2007).

Nowadays, online shopping is a fast growing phenomenon. Growing numbers of consumers shop online to purchase goods and services, gather product information or even browse for enjoyment. Online shopping environments are therefore playing an increasing role in the overall relationship between marketers and their consumers (Koo et al. 2008). That is, consumer-purchases are mainly based on the cyberspace appearance such as pictures, images, quality information, and video clips of the product, not on the actual experience (Brennan et al., 2008; Constantinides, 2004). As the Internet has now become a truly global phenomenon, the number of Internet users worldwide is expected to reach 1.8 billion by 2010 according to the survey of ClickZ Stats, cited in Kotler \& Armstrong (2008). This growing and diverse Internet population means that people having diverse tastes and purposes are now going to the Web for information and to buy products and services. Thus, the impact of these online shopping environments on consumer response necessitates a critical understanding for marketing planning.

\section{Problem statement}

According to the Survey of eMarketer's (Aug, 2009), in 2009, 37.1 million (ages 14+) UK people had Internet access and from that 26.9 million internet users are actually using internet to buy products or services. This represents $72.5 \%$ of UK Internet users ages 14 and older will buy at least one item via the online in 2009. Between 2009 and 2010, the number of online buyers will rise from 26.9 million to 28.0 million (4.9\%). As well as, in 2009, UK business-to-consumer (B2C) online sales (including digital downloads and tickets for travel and events) will total $£ 68.4$ billion which is $14.4 \%$ more than 2008 and $46.7 \%$ more than 2007 as shown in Table.1 and graphical comparison between Internet users \& online buyers (2007-2010) is shown in Fig.1 (eMarketer, August, 2009). 


\begin{tabular}{|l|c|c|c|c|}
\hline \multicolumn{5}{|c|}{ Table.1: UK Online Buyers and Penetration, 2007-2010 } \\
\hline Year & 2007 & 2008 & $2009^{*}$ & $2010^{*}$ \\
\hline $\begin{array}{l}\text { Internet Users ages 14 } \\
\text { (millions) }\end{array}$ & 34.3 & 35.8 & 37.1 & 38.4 \\
\hline $\begin{array}{l}\text { Online buyers ages } 14^{+} \\
\text {(millions) }\end{array}$ & 24.7 & 25.9 & 26.9 & 28.0 \\
\hline $\begin{array}{l}\text { Online buyers \% of Internet } \\
\text { Users }\end{array}$ & $72.0 \%$ & $72.3 \%$ & $72.5 \%$ & $72.9 \%$ \\
\hline Online sales (billions) & $£ 46.6$ & $£ 59.8$ & $£ 68.4$ & $£ 78.5$ \\
\hline Note: * converted at average annual exchange rates (projected for future years) \\
\hline
\end{tabular}

Source: Adapted from eMarketer (August, 2009); available at www.eMarketer.com

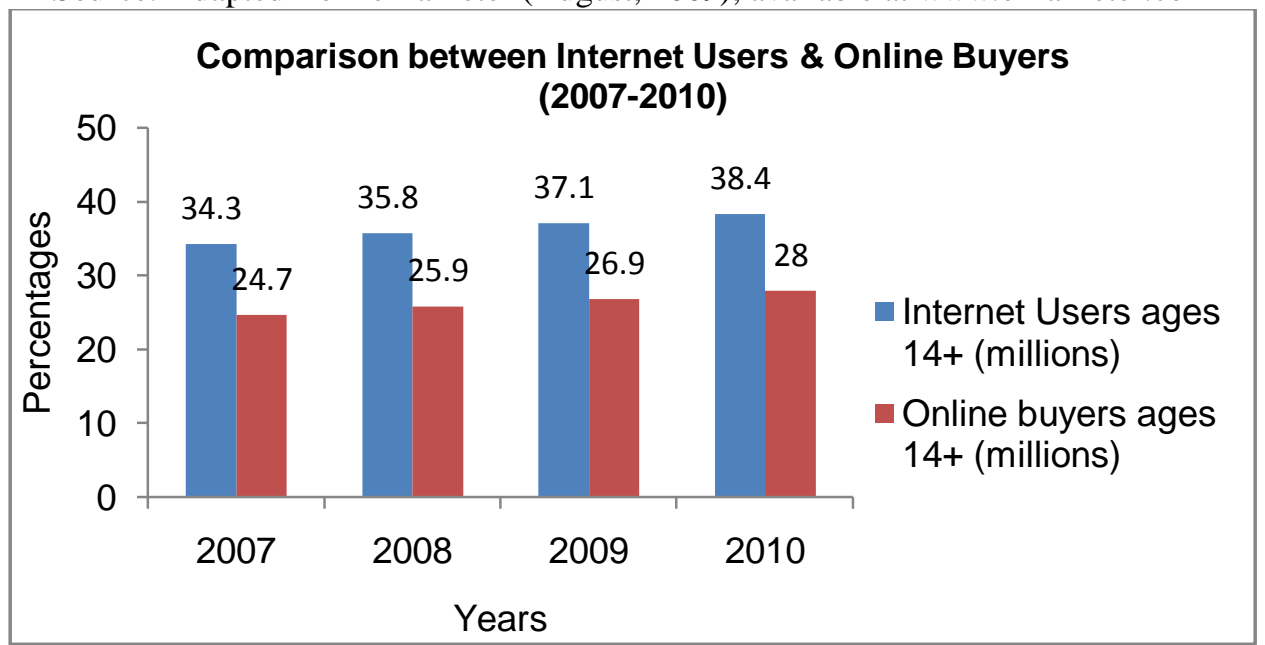

Fig.1: Comparison between Internet Users \& Online Buyers (2007-2010)

Though online users are increasing frequently, online shoppers are not increasing as many as users increasing. There might have some reasons. Research on online shopping has been carried out for the last two decades. Since then consumers' beliefs to online shopping is increasing, but how much their perceptions are about online shopping still need to be researched. As said by Monsuwé et al, (2004) customers attitudes can be change by demographic, geographic or security reasons, thus in view of that it is needed to investigate how the content and presentation of product and service information affect consumers' willingness to patronize an online store and also needed to identify several factors affecting online consumers' purchase behaviour as well as their perception and satisfaction in UK, particularly in the North Wales (Wrexham) area.

\section{Research Objectives:}

Therefore, the aim of this research is to explore consumer perceptions of Internet-based e-retailing and scrutinize the major factors that influence the online consumer's shopping behaviour in decision-making process. The specific objectives of the research are:

1. To explore the reasons why despite increase in internet users, online shopping has not been increasing.

2. To discover the individual factors that might, on one hand, prompt a buyer to make an online purchase decision and on the other hand, restrain from such decisions.

3. Finally to put forward some recommendations to the e-tailers in order to improve the current situation.

\section{Literature Review:}

According to Kotler \& Keller (2009), a buyer goes through five stages while making a decision to purchase. These stages are best explainable when a buyer goes for buying costly items, such as a house, a car, diamond jewellery etc. However, in day- to- day purchase, consumers may not go through all these stages, since some commodes do not need information, and based on buyer's previous experience they will visit a store for the purchase. These stages are (Figure 1): "problem recognition, information search, evaluation of alternatives, purchase decision, and purchase behaviour" (Kotler \& Keller 2009). 
Figure 1

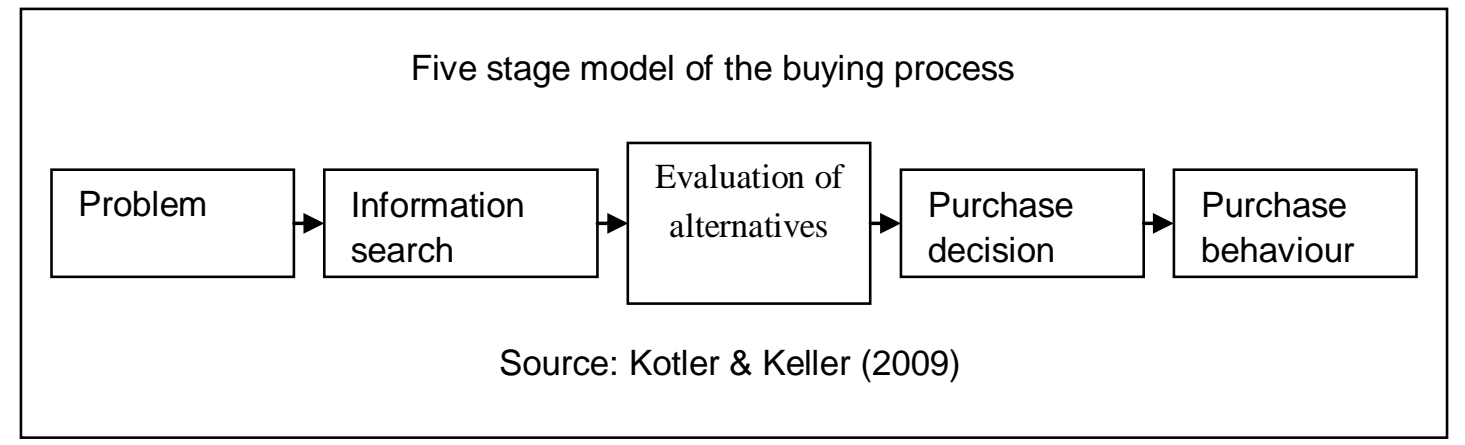

In addition, many marketing activities (e.g. relationship marketing, marketing research, data mining, promotion/communications, supply chain management, sales and purchasing and after sales support) are now technology enabled due to the increasing expansion of online marketing via the Internet (O'Connor \& Galvin, 2001). Companies are now using the Internet to build closer relationships with consumers and marketing partners. Besides competing in traditional marketplaces, they now have access to exciting new market spaces. Moreover, through the Internet, consumers can learn about design, order, and pay for products and services, without ever leaving home and then, through the wonders of express delivery, they can receive their purchases in short time. From virtual reality displays that test new products to online virtual stores that sell them, the technology explosion is affecting every aspect of marketing. The Internet has now become a truly global phenomenon (Srisuwan \& Barnes, 2008; Teng et al., 2007).

Besides, Jayawardhena et al. (2007) in their study considered the purchasing orientation of potential buyers and assessed its impact on purchase behaviour, but found that individual orientation is independent of purchasing decision, which reinforces the views of Liu et al. (2008) and Sorce et al. (2005) that every stage of the purchasing decision making cycle may have impact on a potential buyer's decision to buy online or not. Demangeot and Broderick (2007) reported that "information search experiences affect the attitudes towards the site and its brands". In the Koo et al. (2008) study, which was conducted on 279 online customers in Korea, it was found that " 32.5 per cent use the internet for news and information, 32.5 per cent for communication, 7.5 per cent use it for entertainment while 7.1 percent for online shopping".

Furthermore, in consistent with Gay et al. (2007), Yun and Good (2007), Lee and Lin (2005), Rajamma et al. (2007), Kim and Kim (2004), Ramus and Nielsen (2005), Ladson and Fraunholz (2005), Kramarae and Kramer (1995), Welch (1995), Rathmell et al. (1998), Johnstone (1999), Singh (2004), Smith \& Chaffey (2002), and Canavan et al. (2007), : consumer satisfaction and purchase decision on online shopping depends on few more issues. These are: e-store image, delivery and customer services, service quality and purchase behaviour, personalisation, motivations for online purchase, trust, reliability, privacy, transaction and cost, incentive programmes, web-site design, online interactivity, merchandise motivation, assurance, convenience (or Hassle Reduction), pragmatic motivation, responsiveness, consumer risk assessment etc.

Following from the above consideration, this research will find out the answers to the following specific question within a sample in Wrexham township, that are likely to formulate the findings of the research and from where attempts will be made to draw generalizations. Therefore, in the context of consumer satisfaction in online shopping, the research question is:

\section{"What individual factors motivate a buyer to purchase online as well as restrain to purchase online"?}

\section{Research Methodology:}

The nature of this research is descriptive and the goal of this research is to explore the consumer's satisfaction towards online shopping and to measure how these factors are extensive. For this reason, a survey was conducted in Wrexham area to collect primary data by using questionnaire which contains 23 relevant questions regarding online shopping. A simple random process has been used to collect data for this research. A quantitative analysis has been used to analyse the research data. All questions are closed-ended because all possible answers were given to the respondents. Also, such questions are easy to use, reduce interviewer bias, reduce respondent bias and facilitate coding and tabulation (Collis \& Hussey, 2009). The Likert scale has been used for the main research questions. 
The data have been analysed by using SPSS 11.5 software. A list of data collection of this research has been given below.

\begin{tabular}{|c|c|c|c|}
\hline Data collection places & $\begin{array}{c}\text { Total distributed } \\
\text { questionnaires }\end{array}$ & $\begin{array}{l}\text { Total collected } \\
\text { questionnaires }\end{array}$ & $\begin{array}{c}\text { Total days of data } \\
\text { collection }\end{array}$ \\
\hline Tesco, Wrexham & 15 & 12 & \multirow{5}{*}{$\begin{array}{c}\text { 4 January, } 2010 \\
\text { to } \\
17 \text { January, } 2010\end{array}$} \\
\hline ASDA, Wrexham & 15 & 13 & \\
\hline Sainsbury, Wrexham & 15 & 13 & \\
\hline Market Place, Wrexham & 15 & 14 & \\
\hline Glyndŵr University, Wrexham & 10 & 8 & \\
\hline Total & 70 & 60 & 14 Days \\
\hline
\end{tabular}

\section{Analysis and Findings:}

The findings of this research are presented in three steps i.e. filtering questions, then mains reasons or factors which attract consumers to do shopping online and then main reasons or obstacles which discourage consumers from shopping online. Therefore, from the analysis, it is found that nearly $90 \%$ respondents use internet daily but most of the respondents do not use internet daily to buy products. Nearly half of the total respondents' opinions were that they would only use the internet to buy products when the need arise to do so.

\section{Motivating factors of online shopping:}

From the interpretation of findings, it is observed that Internet shopping was considered by almost everyone (90\%) to be convenient. The store is always open (24/7), and it is easy, less stress and time saving to shop from home. Participants also seemed to agree that internet shopping gives access to a large range of stores and products from the entire world and offers best price to their consumers.

Besides, respondents' also expressed their opinion that "online shopping is helpful for old and disable people". Nearly $92.5 \%$ respondents agreed with this statement and only $7.5 \%$ participants' were neutral about it. Interestingly no respondents were disagreed with this statement. Also, more than two-third respondents (77.5\%) agreed that it is easy to navigate the websites of online shops, though $17.5 \%$ respondents were neutral and $5 \%$ respondents disagreed with this issue. Moreover, nearly two third respondents somehow agreed that online service quality is good while around one third of respondents were given neutral opinion about online service quality.

When asked about 'online ordering systems' respondents have given different opinions. More than $50 \%$ respondents were considered that products' ordering in online was easy. Rest of them were either neutral or disagreed. Respondents also have given interesting opinions about shopping fun of online shopping. Nearly two third respondents are agreed that online shopping is fun for them, but one fifth of respondents have given a neutral opinion and more than one tenth of respondents disagree that online shopping is fun.

\section{Inhibitions of online shopping:}

Respondents were given a wide range of opinions about online shopping's inhibitions. Delivery systems faults, online payment systems, personal privacy and personal customer services were the main concerning issues regarding online shopping. Nearly two third of the respondents thought that high delivery costs and product's delivery delaying were another important inhibitions of online shopping, though nearly one third of respondents were given neutral opinions about these two inhibitions of online shopping. Again nearly two third of the respondents' are of the opinion that online payment systems are not trustworthy and personal privacy can be lost while paying through online with a debit or credit card, though nearly one third respondents' opinions are different. One more important inhibition of online shopping', which increases anxiety, is the lack of online customer services. Consumers do not get personal customer services while shopping online. Respondents also gave mixed opinions on products returning policies. Half of the respondents' opinions are that online products' returning policies were not good, though nearly one third of the respondents were neutral and rest of the respondents have disagreed with the rest of the respondents. Nearly half of the respondents thought that products' mixing up at delivery time was another inhibition of online shopping but nearly one third respondents were not given any supporting or opposite opinion about this inhibition.

\section{Hypothesis Testing}

Usually, in quantitative study tests of significance are used to decide whether certain inferences can be drawn regarding any differences or relationships between variables. To do these significant tests SPSS11.5 software has been used. SPSS automatically calculates the significance (or p-value), which is the probability of the null hypothesis $\left(\mathrm{H}_{0}\right)$, being accepted. Hence the level of probability of $5 \%$ or less is commonly taken as an appropriate level for most general research including this study. 
As a result,

$\mathrm{H}_{0}$ accepted if the significance level is greater than $0.05(\mathrm{p}>0.05)$

$\mathrm{H}_{0}$ rejected if the significance level is less than $0.05(\mathrm{p}<0.05)$

Thus, the first hypothesis of this study is:

$\mathbf{H}_{1}$ : A significant number of consumers still buy their products because online shopping motivate them to shop online and they thing it is convenience to them. So the hypothesis is-

Null Hypothesis $\left(\mathbf{H}_{\mathbf{O}}\right)$ : Online shopping is not convenient for the consumers.

Alternative Hypothesis $\left(\mathbf{H}_{\mathbf{A}}\right)$ : Online shopping is convenient for the consumers.

Where the term 'convenient' considered the following variable: time saving, information availability, opening time, less expensive, less stress, best offers, helpful for old and disable people, service quality, easy navigation, easy ordering system, and shopping fun.

The SPSS outputs for normal curve and one sample test for hypothesis -1 are shown in the Fig-1, Table1 and Table2 respectively. As Likert scale was used in the main research question of this study where $1=$ strongly disagree, $2=$ disagree, $3=$ neutral, $4=$ agree, and $5=$ strongly agree and 3 (neutral) is the middle point of this scale. So ' 3 ' has been chosen as test value for this one sample t-test.

\section{Fig-1:Nornal Curve}

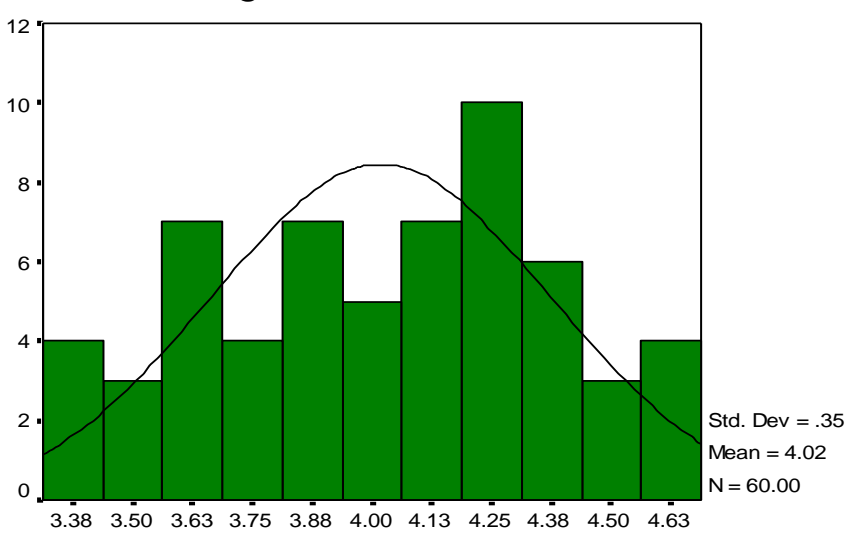

Avg. Satisfaction

Table-1: One-Sample Statistics

\begin{tabular}{|l|r|r|r|r|}
\hline & $\mathrm{N}$ & Mean & Std. Deviation & $\begin{array}{c}\text { Std. Error } \\
\text { Mean }\end{array}$ \\
\hline Time Saving & & 60 & 4.47 & .812 \\
Information Availability & 60 & 4.28 & .846 & .105 \\
Less Stress & 60 & 3.83 & .867 & .109 \\
Less Expensive & 60 & 4.27 & .733 & .112 \\
Best Offers & 60 & 3.98 & .813 & .095 \\
Helpful for old and disable & 60 & 3.95 & .852 & .105 \\
people & 60 & 3.15 & .954 & .110 \\
Service Quality & 60 & 4.37 & .712 & .123 \\
Easy Ordering System & & 3.87 & .982 & .092 \\
Shopping fun & & 60 & & .127 \\
\hline
\end{tabular}

Table-2: One-Sample Test

\begin{tabular}{|c|c|c|c|c|c|c|}
\hline & \multicolumn{6}{|c|}{ Test Value $=03$} \\
\hline & \multirow[b]{2}{*}{$\mathrm{t}$} & \multirow[b]{2}{*}{ df } & \multirow[b]{2}{*}{ Sig. (2-tailed) } & \multirow{2}{*}{$\begin{array}{c}\text { Mean } \\
\text { Difference }\end{array}$} & \multicolumn{2}{|c|}{$\begin{array}{c}95 \% \text { Confidence Interval } \\
\text { of the Difference }\end{array}$} \\
\hline & & & & & Lower & Upper \\
\hline Time Saving & 13.985 & 59 & .000 & 1.47 & 1.26 & 1.68 \\
\hline Information Availability & 11.756 & 59 & .000 & 1.28 & 1.06 & 1.50 \\
\hline Less Stress & 7.447 & 59 & .000 & .83 & .61 & 1.06 \\
\hline Less Expensive & 13.378 & 59 & .000 & 1.27 & 1.08 & 1.46 \\
\hline Best Offers & 9.371 & 59 & .000 & .98 & .77 & 1.19 \\
\hline $\begin{array}{l}\text { Helpful for old and } \\
\text { disable people }\end{array}$ & 8.635 & 59 & .000 & .95 & .73 & 1.17 \\
\hline Service Quality & 1.218 & 59 & .228 & .15 & -.10 & .40 \\
\hline Easy Ordering System & 14.862 & 59 & .000 & 1.37 & 1.18 & 1.55 \\
\hline Shopping fun & 6.834 & 59 & .000 & .87 & .61 & 1.12 \\
\hline
\end{tabular}


From Table2, it has been seen that the significant value of all variable is less than 0.05 except the variable 'Service Quality' whose value $(0.228)$ is greater than 0.05 . Since the first hypothesis $\left(\mathrm{H}_{1}\right)$ was developed based on these variables where the significant value of 8 variables out of 9 (time saving, Information Availability, Less Stress, less expensive, Best Offers, helpful for people, Easy Ordering System \& Shopping fun) are less than 0.05; as a result null hypothesis $\left(\mathbf{H}_{\mathbf{O}}\right)$ is rejected and alternative hypothesis $\left(\mathbf{H}_{\mathbf{A}}\right)$ is accepted. So for hypothesis $1\left(\mathrm{H}_{1}\right)$, it can say that Online shopping is convenient to the consumers.

$\mathbf{H}_{2}$ : A significant number of online buyers did not execute the final act of purchase because of unreliable online delivery system as well as personal privacy or security concerns during the early stages of buying process. So the hypotheses is-

Null Hypothesis $\left(\mathbf{H}_{\mathbf{O}}\right)$ : Online shopping is not reliable and trustworthy to the consumers.

Alternative Hypothesis $\left(\mathbf{H}_{\mathbf{A}}\right)$ : Online shopping is reliable and trustworthy to the consumers.

Where the hypothesis considered the following variables: payment security, personal information privacy, product delivery, unclear warranties \& return policies, Lack of customer service and Personal skills. For hypothesis- $2\left(\mathrm{H}_{2}\right)$ the test value is also 3 due to the same reason mentioned in hypothesis-1 $\left(\mathrm{H}_{1}\right)$ and all the sampling data collected for hypothesis-2 $\left(\mathrm{H}_{2}\right)$ is also normally distributed (Fig2).

The SPSS outputs of normal curve and one sample test for hypothesis -2 are shown in the Fig.2, Table 3 and Table4 respectively.

\section{Fig-2:Normal Curve}

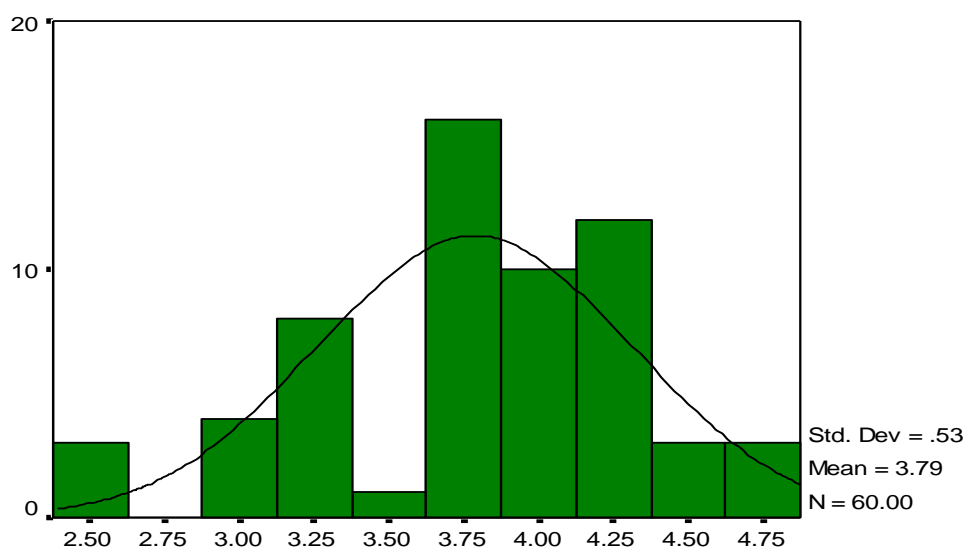

Average Satisfaction

Table-3: One-Sample Statistics

\begin{tabular}{|l|r|r|r|r|}
\hline & $\mathrm{N}$ & Mean & Std. Deviation & $\begin{array}{c}\text { Std. Error } \\
\text { Mean }\end{array}$ \\
\hline Payment Security & 60 & 3.90 & .838 & .108 \\
Personal information privacy & 60 & 3.88 & .825 & .107 \\
product delivery & 60 & 3.57 & 1.064 & .137 \\
& & 3.70 & 1.030 & .133 \\
Warranties, return policies & 60 & 3.62 & 1.075 & .139 \\
Lack of customer service & 60 & 4.05 & .891 & .115 \\
Personal skills & 60 & 691 & \\
\hline
\end{tabular}

Table-4: One-Sample Test

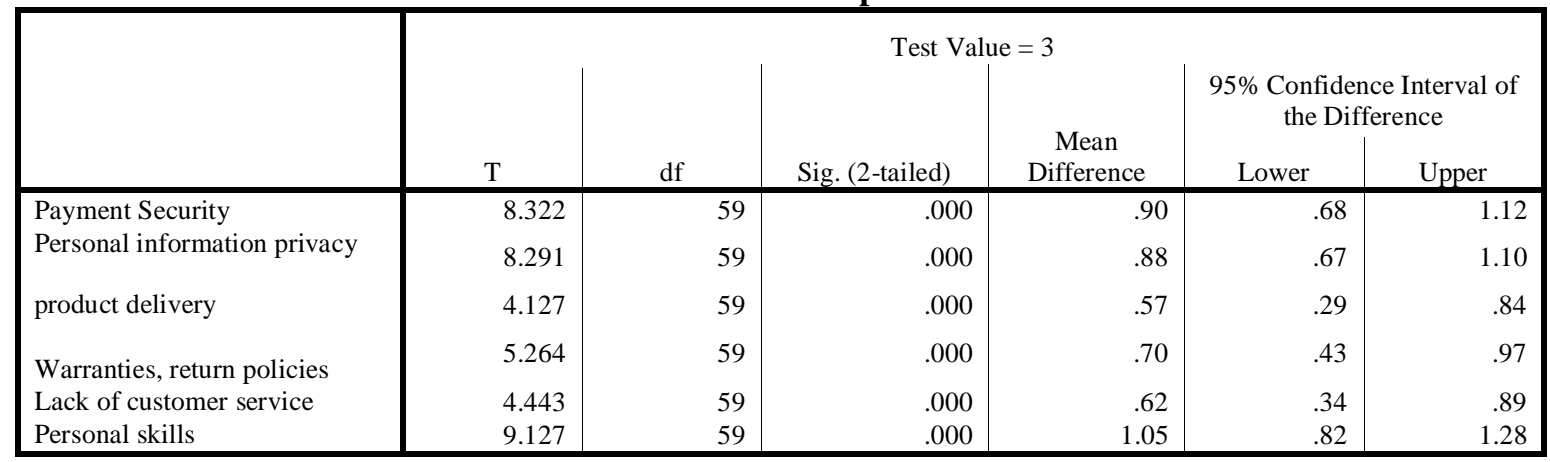


From Table 4, it can be said that the significant value of all variables is less than 0.05 . As the second hypothesis $\left(\mathrm{H}_{2}\right)$ was derived from these variables and their significant value are less than 0.05 , thus null hypothesis $\left(\mathbf{H}_{\mathbf{O}}\right)$ is rejected and alternative hypothesis $\left(\mathbf{H}_{\mathbf{A}}\right)$ is accepted. So for hypothesis-2 $\left(\mathbf{H}_{\mathbf{2}}\right)$, it can be conclude that unreliable online delivery system as well as personal privacy or security concerns have a significant impact on online shopping.

\section{Conclusion}

The endeavour of this study is to identify the motivating factors towards online shopping as well as inhibitions of online shopping. Therefore, from the findings it was found that consumers purchasing decisions were dependent on various factors. All these motives motivate consumers to purchase products through online. According to consumers' opinions, 'time saving' is the most important motivating factor for online shopping. Again 'information availability', 'open 24/7', 'huge range of products/ brands', 'reasonable prices', 'various offers for online products', 'easy ordering system', and 'shopping fun' are other motivating factors for online shopping respectively. In contrast, when respondents were asked about the inhibitions of online shopping, it was found from the findings that, 'online payment system', 'personal privacy or security issues 'delaying of delivery', 'products mixing up at delivery time' and 'products return policies', and lacks of personal customer service' are the main inhibitions of online shopping to the respondents. It was also observed that online shopping is not trustworthy and reliable to some consumers due to only online payment system and personal privacy. In addition, online security is a major concern for the consumer particularly in terms of fraud, privacy and hacking. The concerns for online consumers' as well as online organisations, relating to online security as 'hackers, vandals and viruses' penetrate both vulnerable personal and corporate security system. The main drawback of any contraventions in security or privacy is the loss of trust and reputation, which may affect customer confidence, which can be very damaging for web based vendors.

\section{Recommendations for Online Sellers:}

Based upon the findings and discussion of this study, the following recommendations are presented for the online sellers to make online shopping more popular, convenient, reliable and trustworthy.

- Transaction security and consumers data safety are principal concerns of online customers purchasing products or services online. Therefore online vendors can assure their consumers' by offering personal information privacy protection policy and guarantee for transaction security by improving their technological systems.

- Retailers should be careful about the annoying factors of online shopping such as being unable to access the website, long delays in completing online orders, inconsistencies in the items available online, mistakes in filling orders, and the hassle of returning goods.

- Online sellers can be more concerned about delivery times and delivery charge and product return policies. They can make it easier, quicker and reliable, so that consumers can enjoy the online shopping experience.

\section{References}

[1] Brennan, R., Baines, P., Garneau, P. \& Vos, L. (2008). Contemporary Strategic Marketing. $2^{\text {nd }}$ Ed., New York: Palgrave Macmillan.

[2] Constantinides, E. (2004). Influencing the online consumer's behaviour: the Web experience. Journal of Internet Research, 14(2), pp111-126.

[3] Collis, J. \& Hussey, R. (2009). Business Research: A practical guide for Undergraduate and Postgraduate students. $3^{\text {nd }}$ Ed., Basingstoke: Palgrave MacMillan.

[4] Canavan, O., Henchion, M. \& O'Reilly, S. (2007). The use of the internet as a marketing channel for Irish speciality food. International Journal of Retail \& Distribution Management, 35 (2), pp 178-195.

[5] Demangeot, C. \& Broderick, A. J. (2007). Conceptualising consumer behaviour in online shopping environments. International Journal of Retail \& Distribution Management, 35(11), pp 878-894.

[6] Gay, R., Charlesworth, A. \& Esen, R. (2007). Online Marketing: a customer-led approach. New York : Oxford University Press.

[7] Jayawardhena, C., Wright, L.T. \& Dennis, C. (2007). Consumers online intentions, orientations and segmentation. International Journal of Retail \& Distribution Management, 35 (6), pp 515-526.

[8] Johnstone, P. (1999). Financial Crime: Prevention and Regulation in the Intangible Environment. Journal of Money Laundering Control, 2(3), pp 253-263.

[9] Kim, E. Y. \& Kim, Y. K. (2004). Predicting online purchase intentions for clothing products. European Journal of Marketing, 38(7), pp 883-897.

[10] Koo, D.M., Kim, J.J. \& Lee, S.W. (2008). Personal values as underlying motives of shopping online. Asia Pacific Journal of Marketing and Logistics, 20(2), pp 156-173.

[11] Kotler, P. \& Armstrong, G. (2008). Principles of Marketing. $12^{\text {th }}$ Ed., New Jersey: Pearson Education Ltd.

[12] Kotler, P. \& Keller, L. K. (2009). Marketing Management. $13^{\text {th }}$ Ed., New Jersey: Pearson Education Ltd.

[13] Kramarae, C. \& Kramer, J. (1995). Legal snarls for women in cyberspace. Internet Research: Electronic Networking Applications and Policy, 5(2), pp 14-24.

[14] Ladson, A. \& Fraunholz, B. (2005). Facilitating online privacy on e-Commerce websites: an Australian experience. Journal of Information, Communication and Ethics in Society, 3(2), pp 59-68. 
[15] Lee, G.G. \& Lin, H.F. (2005). Customer perceptions of e-service quality in online shopping. International Journal of Retail \& Distribution Management, 33(2), pp 161-176.

[16] Liu, X., He, M., Gao, F. \& Xie, P. (2008). An empirical study of online shopping customer satisfaction in China: a holistic perspective. International Journal of Retail \& Distribution Management, 36(11), pp 919-940.

[17] Monsuwé, T.P., Dellaert, B.G.C. \& Ruyter, K. D. (2004). What drives consumers to shop online?. International Journal of Service Industry Management, 15(1), pp: 102-121.

[18] O'Connor, J. \& Galvin, E. (2001). Marketing in the Digital Age. $2^{\text {nd }}$ Ed., Harlow: Financial Times/ Prentice Hall.

[19] Rajamma, R. K., Paswan, A. K. \& Ganesh, G. (2007). Services purchased at brick and mortar versus online stores, and shopping motivation. Journal of Services Marketing, 21(3), pp 200-212.

[20] Ramus, K. \& Nielsen, N.A. (2005). Online grocery retailing: what do consumers think”, International Research, 15 (3), pp 335-352.

[21] Rathmell, A., Overill, R., Valeri, L. \& Gearson, J. (1998). The IW Threat from Sub-State Groups: An Interdisciplinary Approach. Journal of Financial Crime, 6(2), pp 146-156.

[22] Singh, A.M. (2004). Trends in South African Internet banking. Journal of Aslib Proceedings, 56(3), pp 187-196.

[23] Smith, P.R. \& Chaffey, D. (2002). E-Marketing Excellence. Butterworth Heinemann.

[24] Sorce, P., Perotti, V. \& Widrick, S. (2005). Attitude and age differences in online buying. International Journal of Retail \& Distribution Management, 33(2), pp 122-132.

[25] Srisuwan, P. \& Barnes, S. J. (2008). Predicting online channel use for an online and print magazine: a case study. Journal of Internet Research, 18(3), pp 266-285.

[26] Teng, L., Laroche, M. \& Zhu, H. (2007). The effects of multiple-ads and multiple-brands on consumer attitude and purchase behaviour. Journal of Consumer Marketing, 24 (1), pp 27-35.

[27] Welch, J.M. (1995). Stalking and anti-stalking legislation: A guide to the literature of a new legal concept. Reference Services Review, 23(3), pp 53-68.

[28] Yun, Z.S. \& Good, L.K. (2007). Developing customer loyalty from e-tail store image attributes. Journal of Service Quality, 17(1), pp 4-22.

[29] http://www.eMarketer.com. [Electronically accessed on $14^{\text {th }}$ November, 2009]. 